\title{
Driving Industry Growth through Academic Excellence: A Study on the Strategic Contribution of University-Industry Knowledge Transfer in Revamping Manufacturing SMEs in Developing Economies
}

\author{
Fanny Saruchera \\ Marian Tukuta \\ Gladys R. Ndoda \\ Mike N. Sikwila \\ Chinhoyi University of Technology, Zimbabwe \\ Email: sarucheraf@yahoo.com / fsaruchera@cut.ac.zw
}

Doi:10.5901/mjss.2014.v5n14p252

\begin{abstract}
The theory of university-industry knowledge transfer and its ability in transforming the fortunes of SMEs as well as its general applicability to driving industry growth has commanded some research interest worldwide though not much has been written of developing economies. The authors investigate the strategic contribution of academic excellence, through university-industry collaborations, in revamping SMEs in the manufacturing sector. The study commenced with a review of current literature on university-industry collaborations which provided a basis for evaluating five university-SME collaborations over a period of five years. The study found that the lack of professionalism and management incompetency in most SME organizations was undermining the contribution made by the academic institutions in promoting industrial growth in Zimbabwe. We examine the contribution of academic excellence as an engine for industrial growth in SME's in developing economies such as Zimbabwe. The study is anchored on promoting industry (SMEs)-university collaborations where universities and other institutions of higher and tertiary education are required to produce highly knowledgeable graduates who are expected to be the drivers of economic development and growth, in the same manner; industrialists are expected to participate in the development of relevant curriculum programmes in universities. Built on some preceding evidence, the paper confirms that university-industry collaborations supported by the state, promote new SMEs and universities' capabilities through complementing one another. Moreover, the paper articulates on how such a platform could be created.
\end{abstract}

Keywords : SMEs, Developing Economies, Knowledge Transfer, Academic Excellence, University

\section{Introduction}

Though used in various interactions, the expression "university-industry knowledge transfer" has been mostly used to refer to the "exchange of knowledge and technology, between universities and firms" (Rossi, 2010). Debackere (2004:1) specifies a number of situations in which the term applies and these include: when creating start-up firms engaged in the commercial exploitation of university inventions, when performing collaborative research between firms and academic institutions, contract research and academic consulting commissioned by industry, during the development and commercialization of intellectual property rights on the part of universities, co-operation in the graduate education and advanced training for enterprise staff, as well as when exchanging researchers between firms and universities. A vigorous university research base contributes significantly to industrial and economic growth (Tornatzky, 2000). This often occurs through people-embedded knowledge transfer as new graduates move into the workforce. Moreover, this has happened through faculty consulting, seminars, publications, and conferences.

In a research carried out by International Institute for Applied Systems Analysis (IIASA) in collaboration with the Vienna Institute of Demography of Austria (2008), it was noted that human capital formation plays a significant role in a country's economic development. The perspective of the university as a key contributor to wealth generation and economic development has increased over the decades (Mansfield \& Lee, 1996; Dooley \& Kirk, 2007).

The size and scope of university-industry knowledge transfer arrangements have been on the rise in most developed economies over the recent years (Rossi, 2010), while developing economies, particularly in Africa has been 
operating in parallel lines. According to Wang and Lu (2007), a close examination of knowledge transfer literature shows that existing studies on university-industry interactions are either from macro economics perspective and examining the impact of University-industry relations on national or regional innovation system (e.g. Nelson, 1993), or drawing upon social and institutional theories to examine different types of institutional university-industry interactions in relation to knowledge creation and innovation (Etzkowitz and Leydesdorff, 1997). Based on a Chinese context, Wang and Lu (2007) weighed in the existing literature framework by focusing their study on the process of knowledge transfer between university and industry. Notwithstanding the growing interests in investigation on knowledge transfer between universityindustry and informing results from various past studies, current research agrees with Wang and Lu (2007) that most of these studies have been conducted in western countries. Thus, there has not been shortage on literature especially on the features, motivations and effects of university-industry knowledge transfer. Also, theoretical frameworks for developed economies have been posted to complement the vast knowledge transfer literature (Cohen et al., 2002; Geuna, 1999; Link et al., 2007; Peters and Etzkowitz, 1990; Rossi, 2010). However, not much has been done with regard to the role played by the knowledge transfer links in ensuring SMEs' success, worst still, in a developing economy context. Based on this background, the objectives of the study were three-fold: first, to establish the role of academic excellence in revamping SMEs in developing economies such as that of Zimbabwe, and thereby attaining industry development (growth and change), second, to evaluate the extent to which university-industry knowledge transfer enhances SMEs, third, to come up with feasible recommendations to enhance University-Industry Knowledge Transfer linkages in developing economies. While past studies (Dooley \& Kirk, 2007) have focused on "grafting the entrepreneurial paradigm onto academic structures", the current study primarily focuses on embedding academic excellence into SME entrepreneurial structures.

The paper is divided in five sections: It commences by addressing the contextual research problems that motivated the study. Section Two sets out the overall research framework based on literature reviewed from seminal and current sources. The methodological issues of data collection and analysis processes are described in Section Three while Section Four reports and analyzes the major findings from the study. Finally, Section Five concludes the paper by highlighting the theoretical and practical implications of the study's findings and possible suggestions for further research.

\section{Literature Review and Conceptual Outline}

\subsection{The Manufacturing sector in Zimbabwe}

Zimbabwe basically has five sectors which largely contribute to gross domestic product (GDP), and thereby generate wealth and these include: the agriculture, mining, the service sector especially through tourism, manufacturing and construction (CZI, 2010; UNWTO IOM IOHBTO, 2008). The manufacturing sector produces various products for both domestic and foreign markets. Furthermore, we note that Zimbabwe has vast mineral deposits which together with agricultural contribute a substantially to economic growth and development, invariably adding to wealth creation (Ndlovu, Goriwondo and Mashingaidze, 2010). In addition the agricultural sector provides the bulk of raw materials to the manufacturing sector. The manufacturing sector, which is the focus of this study, has been contributing $22 \%$ to the country's GDP which fell from 5\% to 17\% in 2009 (CZI, 2010). The sector supplies 50\% of its output whilst $63 \%$ of its inputs are obtained from agriculture. SMEs have made a major contribution to this output but have been hindered by the apparent challenges that the present study tackle. Bond and Masimba (2002) noted that a long period lies ahead in which damage done to once strong industrial base must be repaired. Such a notation identifies the need to revitalize the manufacturing sector, a part which higher and tertiary education must play.

Kariwo (2011) suggest that Zimbabwe only had one University with 2000 students during and immediately post colonialism but the number has since rose to about 40000 students studying at 12 Universities in Zimbabwe. One, therefore, wonders if tertiary education is really meaningful or it has been just a way of trying to control unemployment rate by delaying someone from seeking a job. According to NewsDay of 31 August 2012, Zimbabwe's struggling manufacturing sector could soon rely on imports to remain afloat due to its failure to compete, underfunding and political uncertainty. According to Goriwondo et al. (2013), manufacturing sector produces value added products that are easily transferable across national and international borders. Zimbabwean manufacturing sector used to contribute immensely to the country`s GDP, contributing $22 \%$ around $2002 / 3$ which has gone down to $17 \%$ in 2007/8 (CZI, 2010). Bond and Masimba (2002) conclude that there is a need to revitalise the manufacturing sector to levels that prevailed in the 1990s.

Goriwondo et al. (2013) recommend that Zimbabwe's manufacturing sector should adopt agile manufacturing for it enables organisations to survive and prosper in a competitive environment where continuous and uninterrupted activity take place in a rapid manner (Cheng et al., 2000). Situations such as intensified competition, turbulent business 
environment, diversified demand, numerous new technological capabilities and utilisation of such technologies call for the agile approach. Enablers of agile manufacturing includes both managerial and technological (Wang, 2006).

\subsection{University-Industry Knowledge Transfer in SMEs}

It has been largely propounded that we are now living in the knowledge-based society in which knowledge has indeed become the strategic source of generating innovation capacities for firms to maintain sustainable competitive advantages in the fast changing business environment (Lambooy, 2004; Lazzeretti and Tavoletti, 2005). Universites have never commanded such an increasing attention from the industry. As economies strive to become knowledge-based, there has been an increasing demand for innovation and this has brought about new challenges for universities to move beyond their traditional role as educational institution and develop more outreach activities in partnerships with industries (Etzkowitz and Leydesdorff, 2001). One of an important means for university to engage with industry is through technology transfer and commercialization activities. According to Wang and Lu (2007), the development of universityindustry knowledge transfer activities embodies a number of institutional and organizational trends as well as government efforts in building up and enhancing firm competitiveness based on effective knowledge creation.

Based on a Hong Kong context, Sharif and Baark (2008) illuminate the role played by university-based technology transfer offices (TTOs) in driving the transfer of research-based knowledge and technology from institutions of higher education to industry. The authors found that, while TTOs originally served primarily to generate additional revenues for their affiliated universities through the creation and commercialization of intellectual property rights, that role has gradually evolved to support innovative start-up companies through technology transfer. SMEs have not been spared of this role. Policymakers increasingly view universities as possible engines of economic growth, via the commercialization of intellectual property through technology transfer using culture as a transmission mechanism (Siegel \& Phan, 2005; Ndoda \& Sikwila, 2013). This observation has been echoed by Markman et al. (2005) who noted that universities, such as Chinhoyi University of Technology, have adopted formal mission statements regarding the role and importance of technology transfer as an accelerator for change as indicated in Figure 1 below:

Figure 1: Re-alignment of CUT's Vision Model

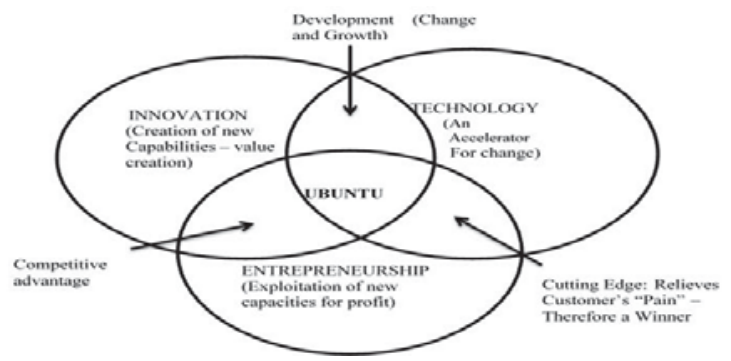

Source: Ndoda, Sikwila and Tukuta (2014).

Tsoukas (2001) claims that new product development calls for 'actionable knowledge for the creation of intellectual property and the identification of new market opportunities.' In a study carried out on SMEs in Taiwan, Huang, Chang and Henderson (2008) noted that operational circumstances change as the process of new product development goes through different stages of its development, and so do challenges faced. Thus Huang et al., (2008) summarized and confirmed the following challenges hindering knowledge transfer between the knowledge provider and the knowledge seeker. 
Table 1: Knowledge Transfer Barriers at different Entrepreneurial stages

\begin{tabular}{|c|c|c|c|}
\hline & $\begin{array}{l}\text { Knowledge Transfer Barriers of } \\
\text { Provider }\end{array}$ & $\begin{array}{l}\text { Knowledge Transfer Barriers of } \\
\text { Seeker }\end{array}$ & Source \\
\hline $\begin{array}{l}\text { Planning stage: } \\
\text { Tacit to tacit }\end{array}$ & $\begin{array}{l}\text { 1. Lacks motivations } \\
\text { 2. Not reliable }\end{array}$ & $\begin{array}{l}\text { 1. Lacks motivations } \\
\text { 2. Lacks absorptive capacity } \\
\text { 3. Lacks retentive capacity }\end{array}$ & $\begin{array}{l}\text { Szulanski (1996); Chang } \\
(2008)\end{array}$ \\
\hline $\begin{array}{l}\text { Developing stage: } \\
\text { Tacit to explicit }\end{array}$ & $\begin{array}{l}\text { 1. Lacks motivation } \\
\text { 2. Not reliable } \\
\text { 3. Lacks teaching capacity }\end{array}$ & $\begin{array}{l}\text { 1. Lacks motivation } \\
\text { 2. Lacks absorptive capacity } \\
\text { 3. Lacks retentive capacity }\end{array}$ & $\begin{array}{l}\text { Szulanski (1996); Chang } \\
\text { (2008) }\end{array}$ \\
\hline $\begin{array}{l}\text { Marketing stage: } \\
\text { Explicit to explicit }\end{array}$ & $\begin{array}{l}\text { 1. Lacks motivations } \\
\text { 2. Not reliable }\end{array}$ & $\begin{array}{l}\text { 1. Lacks motivations } \\
\text { 2. Lacks absorptive capacity } \\
\text { 3. Lacks retentive capacity }\end{array}$ & $\begin{array}{l}\text { Szulanski (1996); Chang } \\
(2008)\end{array}$ \\
\hline $\begin{array}{l}\text { Commercial stage: } \\
\text { Explicit to tacit }\end{array}$ & $\begin{array}{l}\text { 1. Lacks motivation } \\
\text { 2. Not reliable }\end{array}$ & $\begin{array}{l}\text { 1. Lacks motivation } \\
\text { 2. Lacks absorptive capacity } \\
\text { 3. Lacks retentive capacity }\end{array}$ & $\begin{array}{l}\text { Szulanski (1996); Chang } \\
(2008)\end{array}$ \\
\hline Strategy CS or PS & $\begin{array}{l}\text { Various strategies to reduce the } \\
\text { transferring barriers then encourage } \\
\text { performance }\end{array}$ & $\begin{array}{l}\text { Various strategies to reduce the } \\
\text { transferring barriers then encourage } \\
\text { performance }\end{array}$ & $\begin{array}{l}\text { Whittington (1993); Song et } \\
\text { al. (1996); Szulanski (1996) } \\
\text { Chang (2008) }\end{array}$ \\
\hline
\end{tabular}

Source: Huang, Chang, and Henderson (2008:623)

Paul (2001), argue that a large number of SMEs fail because of non financial reasons such as lack of forecasting or planning skills, a lack of skilled human resources and poor management practices. The assertion by Paul (2001) was supported by Zindiye (2008) who said the current financial problems and lack of management skills such as human resources, marketing and general management have to be fully utilised if the sector wish to reduce capital cost of creating new jobs. In spite of the potential of SMEs to provide employment and income to the majority of people in developing countries, their performance has been characterised by low contributions to GDP, low growth rates and the inability to graduate into larger companies (Berry et al., 2001 \& Liedholm 2002). In contrast to large firms, SMEs` poor performance and inability to market their products both domestically and abroad has resulted in limited incomes, and thereby purchase of technology for better production processes (Kimura, 2003). This has been one of their causes of stagnation.

\subsection{University-Industry Linkages Drivers}

Dooley and Kirk (2007) propose that in order for university and industry to establish and sustain collaboration, they must gain mutual benefit from the interactions. The authors summarize the benefits from a university perspective of collaborative research with industrial partners as follows:

$\checkmark$ Access to sources of research funding in addition to their traditional public sources, which allows research managers to deepen their competencies and increase the capacity of research undertaken.

$\checkmark$ Increased access to proprietary technology held by industry that facilitates the discovery process. This technology can take the form of process equipment that increases capacity or speeds up the discovery time.

On the other hand, when examining the industry benefit derived through university-industry collaboration, the key drivers include:

$\checkmark$ Access to base scientific competence built up within the university through public research funding.

$\checkmark$ Access to knowledge (both codified and tacit) that has been developed within the research centre through decades of publicly funded research.

$\checkmark$ Access to world-class academics that are both scientifically and industrially aware of the state of the art.

$\checkmark$ Acquire competitive advantage by gaining access to better leads through faster channels than their competitors, thereby enhancing the product development process.

$\checkmark$ Access to rich sources of highly skilled researchers. Often, collaborative research with university can be more cost-effective since universities may already have the infrastructure in place. 
Figure 2. Conceptual Framework

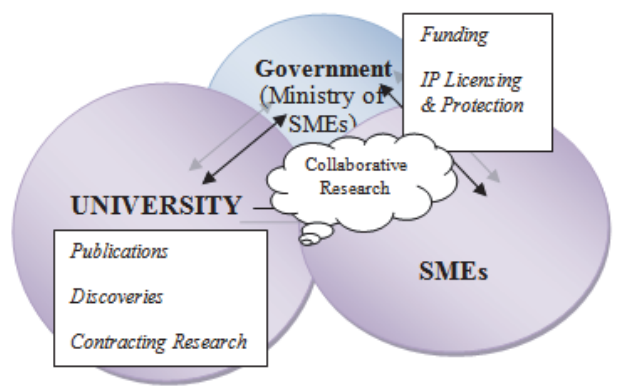

Rappert et al. (1999) views the university as possessing a dual mission of education and discovery research, where the output of the entity is portrayed as a public good. Government acts as the primary funder of academic research, where the research is disseminated as a "free good" to society (which includes industry) through publications. Despite the perspective of some in universities that this is the traditional role of the university, the basic research model of science has only been in the ascendancy from the mid-nineteenth to the mid-twentieth century (Etzkowitz, 2003). Grounded on past findings (e.g. Etzkowitz, 2003; Etzkowitz et al., 2000), the framework in figure 2 above, is based upon the following assumptions and/or propositions:

- Academic researchers have greater levels of freedom in relation to their line of operation;

- sustainability of research was reliant on creative proposal writing (Dooley and Kirk, 2007);

- There is need for total government support (financial, training, patents protection) through a devoted ministry of SMEs;

- Unlike established industries, SMEs, by their nature may not necessarily be able to provide industry funding into the university system especially in the short run.

- There is a significant time lag of knowledge dissemination to the public (Etzkowitz, 2003) thus collaborative research and venture creation could help manage this anomaly.

Thus Santoro (2000) established that university-industry relations can be channeled through four main categories: research support; technology transfer; knowledge transfer; and cooperative research. We add 'collaborative venture creation' and "university-backed startups" to the list, particularly regarding relations with SMEs.

\section{Methodology}

A case study was closely followed and monitored in which Chinhoyi University of Technology (CUT) School of Business Sciences was involved in collaboration venture creation with five production and mining SMEs, who preferred anonymity for the purposes of this study. During the evaluation, knowledge transfer barriers of the provider (School of Business) and seeker (SMEs) were explored based on the characteristics of the knowledge source and the recipient guidelines given by Chang (2008). Progress on the collaborative projects was monitored and evaluated over a period of five years. During the period, the School and the respective SMEs were engaged in collaborative consultancy, research and development. The school provided support to the SMEs in mostly in form of training through seminars and workshops; presentation of research results and expert advice provision in areas such as production, marketing distribution and finance. In special cases, human resources were provided to SMEs in need in form of students on work-related-learning.

\section{Main empirical findings from the case study}

\subsection{Increase in SME Patent grants}

Figure 3 below shows the number of patents granted and those pending as a result of the collaboration between the CUT School of Business and the five SMEs. As noted in the figure, the number of patents granted has been on a continuous rise as a result of the collaboration. The number of patents has a potential to outweigh any expectations as represented by the number of patents still pending in 2014 . 


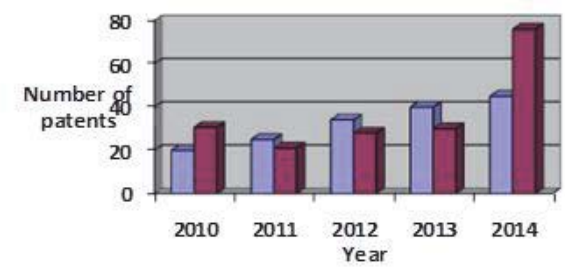

Sales and profits for the SMEs under review

As illustrated by figure 4 below, although the sales have not being consistent, the aggregated profits for the SMEs in the vase have been constantly on the rise, a clear sign that the knowledge transfer arrangement has been working quite well. It might also be argued that profits have continued to take an upward trend even in times where sales have dropped due to Pareto optimality and marketing efficiency. Thus the proper marketing and finance advice have been provided to the SMEs such that they are able to make a profit even when they sell less.

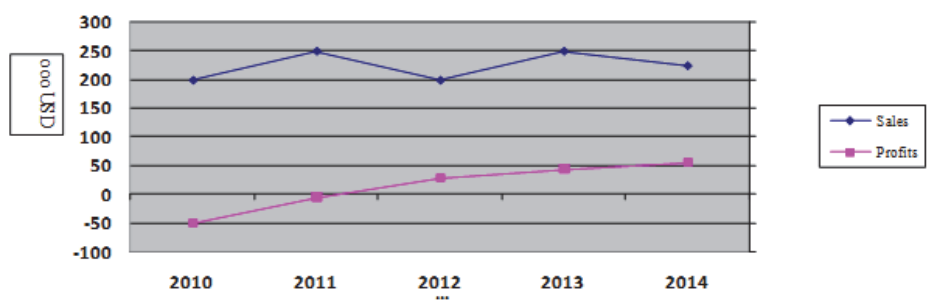

Revamping the CUT School of Business Entrepreneurship program

The CUT Entrepreneurship and Business Management Program was introduced in 2003 to assist the school (faculty) and students in shifting their reliance from employment seeking, but rather employment creation though establishing their own start-up companies. It is the university's policy to promote such activities for the benefit of the university's provincial locale and Zimbabwe at large. The evaluation of the case realized the need to inculcate these entrepreneurial skills in to all university students regardless of discipline. Such a move could instill a sense of creativity in one's area of focus, such as tourism and hospitality.

\subsection{Barriers to progressive knowledge transfer}

Though the knowledge transfer provider (university) did not lack the teaching capacity, it seemed the provider lacked some motivation, particularly during the early years of the collaboration. As the collaboration began to reap some results, the university began to put in place strategies to reduce the transferring barriers then encourage performance. However, on the part of the SMEs involved, there seemed to be lack of motivation, absorptive and retentive capacities (Szulanski, 1996; Chang, 2008). As the SME's output progressed through their respective life cycles, the SMEs slowly managed the barriers.

The study further found out that lack of professionalism and management incompetency in most organizations was undermining the contribution made by academic institutions in promoting industrial growth in Zimbabwe. As outlined earlier on, Zindiye (2008) in full support of Paul (2001), argue that a large number of SMEs fail because of non financial reasons such as lack of forecasting or planning skills, a lack of skilled human resources and poor management practices. The study confirmed this assertion thus the framework for university-SME collaboration is incomplete at least without government support, through a dedicated ministry of SMEs. 


\section{Conclusions and Recommendations}

According to Katsande and Nota (2011) a highly educated labour force is central to the achievement of sustainable economic growth. This means that academic excellence has to be proportional to economic growth. It is high time SMEs should start employing graduates who will bring with them the much needed innovation and creativity necessary to enhance productivity and demand for their products.

Even though some institutions in Zimbabwe already train entrepreneurs, there is need for the curricular to include students setting up student business. There is also need to ensure that institutions offer curriculum which makes it possible to combine education with building a successful business.

The sector should not be sceptical about employing graduates for they are highly productive because they will be aiming to impress so that they land a permanent job and also because they bring with them fresh ideas and a different way of doing business. Normally university students develop self motivated habits and continuous learning.

This study recommended that; there should be a platform where industrialists work with universities to promote continual inflow of highly skilled labour to spearhead industrial development activities since no industry cannot succeed without accompanying supportive universities to provide international research experience in industrial and economic break through.

There is also need to set up Technology Transfer Offices (TTOs) as these are especially crucial in conveying critical information requirements for all parties involved. TTOs are also critical when it comes to resource mobilization as they are possibly, better placed to link up with different arms.

Based on the pilot project success, the study established a need to run the project at a large scale. If all main universities in developing economies such as Zimbabwe could join arms in creating such collaborations, an economic boom could be inevitable.

\section{References}

Berry and Liedholm (2002), Strategic Entrepreneurship and Small firm growth in Ghana, International Small Business Journal, Sage Publications.

Bond, P. and Manyonga, M, (2002), Zimbabwe's plunge, Exhausted Nationalism, Neoliberalsm and the search for Social Justice $2^{\text {nd }}$ Edition: University of Natal Press, Pietersburg.

Cohen, W.M., Nelson, R.R. and Walsh, J. (2002), "Links and impacts: the influence of public research on industrial R\&D", Management Science, Vol. 48, pp. 1-23.

Debackere, K. (2004), "Introduction", Introduction, R\&D Management, Vol. 34 No. 1, pp. 1-2.

Dooley, L. and Kirk, D. (2007), "University-industry collaboration: Grafting the entrepreneurial paradigm onto academic structures", European Journal of Innovation Management, Vol. 10 No. 3, pp. 316-332

Etzkowitz, H. (2003), "Research groups as 'quasi-firms': the invention of the entrepreneurial university", Research Policy, Vol. 32, pp. 109-21.

Etzkowitz, H. and Leydesdorff, L. (1997), "Introduction to special issues on science policy dimensions of the Triple Helix of Universityindustry-government relations", Science \& Public Policy, Vol. 24.

Etzkowitz, H., Webster, A., Gebjardt, C. and Cantisano Terra, B.R. (2000), "The future of the university and the university of the future: evolution of ivory tower to entrepreneurial paradigm", Research Policy, Vol. 29, pp. 313- 30.

Geuna, A. (1999), The Economics of Knowledge Production, Edward Elgar, Cheltenham.

Goriwondo, W, Ndlovu, L.R. and Mashingaidze, M. (2010), The role of value addition to mineral resources in enhancing economic growth A Case for Zimbabwe. National University of Science and Technology.

Huang, H.C., Chang, H.C. and Henderson, S. (2008), "Knowledge Transfer Barriers between Research and Development and Marketing Groups within Taiwanese Small- and Medium-Sized Enterprise High-Technology New Product Development Teams" Human Factors and Ergonomics in Manufacturing, Vol. 18 (6) 621-657

Kariwo M.T. \& Shicha, E. (2011), Education and Development in Zimbabwe, Sense Publishers.

Lambooy, J.G. (2004), "The transmission of knowledge, emerging networks, and the role of universities: an evolutionary approach", European Planning Studies, Vol. 12 No. 5, pp. 643-57.

Lazzeretti, L. and Tavoletti, E. (2005), "Higher education excellence and local economic development: the case of the entrepreneurial university of twenty", European Planning Studies, Vol. 13 No. 3, pp. 475-93.

Link, A., Siegel, D.S. and Bozeman, B. (2007), "An empirical analysis of the propensity of academics to engage in informal university technology transfer", Industrial and Corporate Change, Vol. 16 No. 4, pp. 641-55.

Markman, G., Gianiodis, P., Phan, P. and Balkin, D. (2005), "Innovation speed: transferring university technology to market", Research Policy, Vol. 34 No. 7, pp. 1058-75.

Nelson, R.R. (1993), National Innovation System, Oxford University, New York, NY.

Ndoda, G. R. and Sikwila, M. N. (2013). Ambiculture perspective as an economic development strategy. A case of Zimbabwe. 
International Journal of Management Research and development (IJMRD), Vol. 3, No. 3, June - September, pp. 43-61.

Peters, L. and Etzkowitz, H. (1990), "University-industry connections and academic values", Technology in Society, Vol. 12, pp. 427-40.

Rappert, B., Webster, A. and Charles, D. (1999), "Making sense of diversity and reluctance: academic-industrial relations and intellectual property", Research Policy, Vol. 28, pp. 873-90.

Santoro, M. (2000), "Success breeds success: the linkage between relationship intensity and tangible outcomes in university-industry collaborative ventures", The Journal of High Technology Management Research, Vol. 11 No. 2, pp. 255-73.

Rossi, F. (2010), "The governance of knowledge transfer, European Journal of Innovation Management, Vol. 13 No. 2, pp. $155-171$.

Sharif, N. and Baark, E. (2008), "Mobilizing technology transfer from university to industry: The experience of Hong Kong universities", Journal of Technology Management in China, Vol. 3 No. 1, pp. 47-65.

Siegel, D. and Phan, P. (2005), "Analyzing the effectiveness of university technology transfer: implications for entrepreneurship education", in Liebcap, G. (Ed.), Advances in the Study of Entrepreneurship, Innovation, and Economic Growth, JAI Press, Amsterdam.

Song, X. M., Sabrina, M. N., \& Zhao, Y. (1996). Managing R\&D-marketing integration in the new product development process. Industrial Marketing Management, 25, 545-553.

Song, X. M., van der Bji, H., \&Weggeman, M. (2005). Determinates of the level of knowledge application: A knowledge-based and information-processing perspective. Journal of Product Innovation Management, 22, 430-444.

Szulanski, G. (2000). The process of knowledge transfer: A diachronic analysis of strictness. Organizational Behavior and Human Decision Processes, 82, 9-27.

Tsoukas, H. (2001).What is organizational knowledge? Journal of Management Studies, Vol. 38, pp. 973-993.

UNWTO OMT IOHBTO. (2008). World tourism arrivals: from 800 million to 900 million in two years. World Tourism Organization: Spain.

Wang, Q. (2006). Quality Assurance - Best Practices for Assessing Online Programs. International Journal on E-Learning, 5(2), 265274. Chesapeake, VA: AACE.

Wang, Y. and Lu, L. (2007), Knowledge transfer through effective university-industry interactions: Empirical experiences from China, Journal of Technology Management in China, Vol. 2 No. 2, pp. 119-133

Whittington, R. (1993). What is strategy: Does it matter? New York: Routledge.

Zindi, I. (2014) Report on Small and Medium Enterprises, Vol. 40 No. 30, Parliament of Zimbabwe. 